\title{
Use of mouthwashes in patients with oral and oropharyngeal cancer
}

\author{
- José Narciso Rosa Assunção Júnior Discipline of Stomatology, School of Dentistry, Metropolitan University of Santos, \\ Santos, SP, Brazil • Victor Perez Teixeira Discipline of Stomatology, School of Dentistry, Metropolitan University of Santos, \\ Santos, SP, Brazil • Celso Augusto Lemos Department of Stomatology, School of Dentistry, University of São Paulo, São \\ Paulo, SP, Brazil
}

\begin{abstract}
Objective: To evaluate the use of mouthwashes in patients with oral and oropharyngeal cancer. Materials and methods: Fifty-three patients were interviewed through a specific questionnaire at two reference centers for diagnosis and treatment of cancer. The Case Group consisted of 33 patients with final diagnosis of epidermoid carcinoma of the mouth and oropharynx. The Control Group consisted of 20 patients attended to by services not connected with oncology. Results: In the Case Group, $81.8 \%$ did not make use of dental floss, showing statistically significant difference from the Control Group ( $p=0.036$ ). As for toothbrushing, we noticed a contrary behavior in which the Cases brushed more times per day than the Controls. The Control Group made less use of mouthwashes when compared to the Case Group, which used it more times per day ( $\mathrm{p}=0.028)$. Patients in the Case Group smoked more than those in the Control Group, with this difference being significant $(\mathrm{p}=0.004)$. The same behavior was observed for alcohol consumption - consumption in milliliters per day during the year $(\mathrm{p}=0.031)$. Relevance: Various risk factors have been associated with cancers of the oral cavity, among them the consumption of alcoholic beverages. The mechanism by which alcoholic beverages cause oral cancer is unknown, but probably involves topical exposure. Conclusion: From this study, we concluded that even with the small casuistic, by means of a stratified analysis, the use of mouthwashes was four times higher in alcohol consumers; however, no increase of risk in smokers, abstainers from alcohol and non-smokers was observed.
\end{abstract}

DESCRIPTORS | Mouth Neoplasms; Risk; Oral Hygiene.

RESUMO | Uso de enxaguatórios em pacientes com câncer de boca e orofaringe • Objetivo: Avaliar o uso de enxaguatórios em pacientes com câncer de boca e orofaringe. Materiais e método: Foram entrevistados 53 pacientes por meio de questionário específico aplicado em dois centros de referência para o diagnóstico e tratamento do câncer. O Grupo Caso foi constituído por 33 pacientes com diagnóstico final de carcinoma epidermóide de boca e orofaringe. O Grupo Controle foi composto de 20 pacientes atendidos em serviços nãoligados à oncologia Resultados: No Grupo Caso, 81,8\% não fazem uso de fio dental, demonstrando diferença estatisticamente significativa em relação ao grupo controle $(\mathrm{p}=\mathrm{0}, 036)$. Quanto à escovação dentária, notamos comportamento contrário, onde os Casos escovam mais vezes por dia do que os Controles. O Grupo Controle fazia menos uso de enxaguatórios quando comparado ao Grupo Caso, que utilizava mais vezes ao dia ( $\mathrm{p}=0,028)$. Os pacientes do Grupo Caso fumavam mais que os do grupo controle, sendo tal diferença significativa $(\mathrm{p}=0,004)$. O mesmo comportamento foi observado no consumo de álcool- consumo em mililitros por dia durante o ano $(\mathrm{p}=0,031)$. Relevância: Vários fatores de risco têm sido associados acânceres da cavidade oral, entre eles o consumo de bebidas alcoólicas. O mecanismo pelo qual bebidas alcoólicas provocam câncer oral é desconhecido, mas provavelmente envolve exposição tópica. Conclusão: Concluímos com este estudo que, mesmo com uma pequena casuística, por uma análise estratificada, o uso de enxaguatório foi quatro vezes maior em etilistas, porém não se observou aumento do risco em tabagistas, abstêmios alcoólicos e não tabagistas.

DESCRITORES | Neoplasias Bucais; Risco; Higiene Bucal

CORRESPONDING AUTHOR | • José Narciso Rosa Assunção Júnior Department of Stomatology, School of Dentistry, University of São Paulo, São Paulo, SP, Brazil • Rua Ceará, 7 Pompéia, Santos, SP, Brazil • 11065-430 E-mail: narciso@usp.br

\footnotetext{
- Received Jan 22, 2015 • Accepted Feb 27, 2015

- Dol http://dx.doi.org/10.11606/issn.2357-8041.clrd.2016.102956
} 


\section{INTRODUCTION}

At present, oral cancer is a serious health prob-

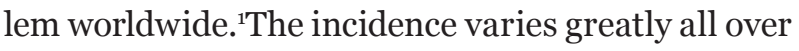
the world. In Brazil, the annual incidence is approximately 15,000 new cases per year. ${ }^{1-3}$ Various risk factors have been associated with cancers of the oral cavity, such as smoking, consuming alcoholic beverages, poor oral health, and infection by the human papillomavirus. ${ }^{3-5}$

Although there are many hypotheses for the effect of alcohol on tumor promotion, the pathogenic mechanisms remain obscure, since alcohol initself is not carcinogenic. ${ }^{6}$ Lemos and Villoria ${ }^{7}$ observed that the mechanism by which alcoholic beverages cause oral cancer is unknown, but probably involves topical exposure, perhaps with a solvent action that increases the penetration of tobacco and other carcinogenic agents.

The association between the use of mouthwashes containing alcohol and the development of oral cancer has been the subject of scientific studies since 1970. Oral antiseptics have been used as a complementary means of performing oral hygiene and is frequently recommended for patients whose mechanical plaque control procedures are inadequate. ${ }^{8}$ The majority of mouthwashes with antiplaque properties contain a certain degree of denatured alcohol, used as a vehicle for delivery of the antimicrobial ingredients. ${ }^{9}$ Alcohol has the function of providing solubility, conservation, stabilization, and an adjuvant antimicrobial effect. ${ }^{10,11}$

Limited and conflicting epidemiological evidence is available about the relationship between the use of alcohol in the oral cavity, in the form of mouthwash solutions, or mouthwashes and oral cancer. Some studies have pointed towards an increased risk of oral cancer, due to the local acetaldehyde production that operates by a mechanism similar to that found after the ingestion of alcoholic beverages ${ }^{12}$.

Based on the controversial literature, the aim of this case-control study was to evaluate not only the association of mouthwashes with oral and oropharyngealcancer, but also the oral hygiene habits of these patients.

\section{MATERIALS AND METHOD}

A total of 53 patients attended at the outpatient clinic of the Center of Oral Diagnosis of the Dental School, University of São Paulo (FOUSP), at the Radiotherapy Service of Santa Casa da Misericórdia de Santos, and at the Head and Neck Surgery Service of the Hospital Municipal de CubatãoDr. Luiz de Camargo da Fonseca e Silva - Pró-Saúde. The Case Group consisted of 33 patients attended at the outpatient clinics of these services, with final diagnosis of epidermoid carcinoma of the mouth and/or oropharynx, with sites in the following anatomic locations. The Control Group was made up of 20 patients attended at other outpatient clinics of the same hospitals and services, without past or present experience of cancer.

Data were collected through a previously established questionnaire, applied by a calibrated researcher. The questions about oral hygiene asked for information about the following aspects: 1) frequency of daily toothbrushing; 2) possible use of dental floss and frequency; 3) if the person noticedany occurrence of bleeding gums; 4) usage of mouthwashes and,if yes, for what reason andwhich, who prescribed it or what made the person decide to buy it,if no, if the person ever used a mouthwash,for how long andwhat is the reason for using it (previous and present).

The distribution of frequencies was used to describe the categorical variables and the measures of central tendency and variability for the numerical or continuous variables. The chi-square frequency test was used to compare the categorical variables regarding the group (Case - Control) in contingency tables, and in 2x2 tables when at least one expected frequency was lower than 5 , the Fisher's exact test was adopted. The Mann-Whitney UTest was used 
to compare the numerical medians of the results regarding the group (Case - Control), when normality of the data was not identified. The level of significance of $5 \%$ was considered in all the statistical tests.

\section{RESULTS}

Of the 33 patients in the case group, 23 were men and 10 were women. The mean age was 59.2 years; the oldest patient was 86 years old and the youngest, 26 years old. The tongue was the most affected site, totaling 14 cases out of 33; followed by the oropharynx ( 8 cases), base of the tongue ( 4 cases), jugal mucosa (2 cases), and floor, edge, soft palate, retromolar region and maxilla, all with 1 case. The majority of the patients were treated with the association of surgery, radiotherapy, and chemotherapy (13 cases), 11 received radiotherapy and chemotherapy, 5 cases were treated exclusively with surgery, 3 cases with surgery and radiotherapy, and 1 case exclusively with radiotherapy.

The patients who wore dental prosthesis totaled 18 cases, and 1 year was the shortest time of use, and 45 years the longest. Of these cases, 4 reported trauma resulting from the dental prosthesis.

Table 1 shows that in $81.8 \%$ of the cases, the patients did not use dental floss, with a similar distribution as for dental floss use in the control group, and this difference was statistically significant $(\mathrm{p}=0.036)$. With regard to gingival bleeding, $87.9 \%$ of the cases did not observe bleeding, and comparison with control cases was shown to be marginally significant $(\mathrm{p}=0.079)$. Regarding tooth brushing, we noted a contrary behavior in which the cases brushed more times per day than the controls, but this difference in behavior was marginally significant.

The use of dental prostheses showed no association with regard to the groups ( $\mathrm{p}>0.05)$.

With respect to mouthwash, the controls made less use of it compared with the case group that used it more times a day $(\mathrm{p}=0.028)$, which was shown to be a statistically significant association (Table 2). Twenty-one of the 33 patients interviewed reported making use of washes. Mouthwashes with alcohol were used by 18 patients, and 3 used the type without alcohol. Eleven patients used mouthwash once a day, 2 patients made use of mouthwashes once a week. Each of the following frequencies of 2x/day, 3x/ day, 4x/day, 5x/day, 5x/week, 3x/week, 2x/week, and $1 \mathrm{x} /$ month were reported by one patient.

Table 3 shows the distribution of habit of smoking or consuming alcoholic beverages. Smoking showed significant difference between the groups ( $\mathrm{p}=0.004$ ), and the quantification of the consumption of tobacco in number of packs per year (quantity of packs of cigarettes and equivalent of other types of cigarettes consumed daily for 1 year) was higher in the case group than in the controls $(\mathrm{p}=0.044)$, and the same behavior was observed for alcohol consumption (consumption in $\mathrm{ml}$ per day during one year) $(\mathrm{p}=0.031)$.

Twenty-three patients reported making use of alcohol, and 10 did not. Of the alcohol consumers, 5 patients drank exclusively fermented beverages, 9 patients drank exclusively distilled beverages, and 9 patients drank distilled and fermented beverages concomitantly. The one who took the most drinks made use of 5 bottles of fermented and 1 liter of distilled beverage per day, for 30 years. The one who drank the least made use of 3 cans of fermented beverage per week for 30 years.

The control group was made up of 20 patients, of whom 10 were men, and 10 women. The mean age was 59.7 years, the oldest patient was 87 years old and the youngest, 43 years of age. Of the 20 patients, 14 did not wear dental prosthesis, and 6 did. Of these 6 patients, 3 reported trauma resulting from the dental prosthesis. The mean time of denture wearing was 21.8 years.

When asked about smoking, 12 patients denied making use of cigarettes, and 8 said they were 
smokers. The mean time of using cigarettes among these patients was 22 years, with 3 years being the shortest and 45 years the longest times. The patient who smoked the least made use of 2 cigarettes per day, and the one who smoked the most used 40 cigarettes/day.

Thirteen patients reported making use of alcohol, and 7 did not. Of the alcohol consumers, 9 patients drank exclusively fermented beverages, 2 patients drank exclusively distilled beverages, and 2 patients drank distilled and fermented beverages concomitantly. The one who took the most drinks made use of 1 bottle of fermented and 1 liter of distilled beverage per day, for 30 years. The one who drank the least made use of 1 can of fermented beverage per week for 10 years.

Eight of the 20 patients interviewed reported making use of mouthwashes. Mouthwashes without alcohol were used by all the patients who made use of these products. Two patients used mouthwashes twice a week, 2 patients used them once a week, and 2 used them once a day. The frequencies of $1 \mathrm{x} /$ fortnight and $1 \mathrm{x} /$ month were reported by one patient each. Two patients reported making use of mouthwashes for 15 years, with this being the longest time of use. Two years was the shortest time of use, reported by 2 patients. Ten years was the time reported by 2 other patients, and 5 years by another 2 patients. Seven patients reported having started to use mouthwashes without professional indication, that is, on their own account. The use indicated by a dentist was reported by a single patient. Another question raised in the interviews was the reason for using mouthwashes. The most prevalent reason was cleaning, reported by 6 patients. Improving breath was the reason given by 1 patient, and other patients said they used mouthwashes to mask the odor of cigarettes.

Table 1 | Distribution of variables referring to oral hygiene habits and use of dentures according to group.

\begin{tabular}{|c|c|c|c|c|}
\hline Variable & Category / Measures & $\begin{array}{r}\text { Ca } \\
\text { Freq. }\end{array}$ & & $p$-value \\
\hline Do you use dental floss? & $\begin{array}{l}\text { No } \\
\text { Yes }\end{array}$ & $\begin{array}{l}27(\mathbf{8 1 . 8}) \\
6(18.2)\end{array}$ & $\begin{array}{l}11(55.0) \\
9(45.0)\end{array}$ & 0.036 \\
\hline Do you observe bleeding in gum? & $\begin{array}{l}\text { No } \\
\text { Yes }\end{array}$ & $\begin{array}{l}29(87.9) \\
4(12.1)\end{array}$ & $\begin{array}{l}13(65.0) \\
7(35.0)\end{array}$ & $0.079 *$ \\
\hline Toothbrushing (freq./day) & $\begin{array}{l}1 \\
2 \\
3 \\
4\end{array}$ & $\begin{array}{c}3(9.1) \\
10(30.3) \\
13(39.4) \\
7(21.2)\end{array}$ & $\begin{array}{c}2(10.0) \\
11(55.0) \\
7(35.0) \\
0(0.0)\end{array}$ & NA \\
\hline Toothbrushing (freq./day) & $\begin{array}{l}\text { Up to } 2 \text { times a day } \\
3 \text { or } 4 \text { times a day }\end{array}$ & $\begin{array}{l}13(39.4) \\
20(60.6)\end{array}$ & $\begin{array}{l}13(65.0) \\
7(35.0)\end{array}$ & 0.071 \\
\hline Wears dentures & $\begin{array}{l}\text { No } \\
\text { Yes }\end{array}$ & $\begin{array}{l}18(54.6) \\
15(45.4)\end{array}$ & $\begin{array}{l}14(70.0) \\
6(30.0)\end{array}$ & 0.265 \\
\hline Time of dental prosthesis use (years) & $\begin{array}{c}\mathrm{N} \\
\text { Variation } \\
\text { Median } \\
\text { Mean (standard deviation) }\end{array}$ & $\begin{array}{c}15 \\
1-45 \\
15 \\
16.2(12.1)\end{array}$ & $\begin{array}{c}6 \\
3-50 . \\
20 \\
21.8(17.1)\end{array}$ & $0.532 *$ \\
\hline
\end{tabular}

p-value obtained by the chi-square frequencies test.

* p-value obtained by the Fisher's exact test. 
Table 2 |.Distribution of variables referring to mouthwash use according to group.

\begin{tabular}{|c|c|c|c|c|}
\hline Variable & Category / Measures & Freq & & $p$-value \\
\hline Use of mouthwash & $\begin{array}{l}\text { No } \\
\text { Yes }\end{array}$ & $\begin{array}{l}12(36.4) \\
21(63.6)\end{array}$ & $\begin{array}{l}12(60.0) \\
8(40.0)\end{array}$ & 0.094 \\
\hline Frequency of mouthwash use & $\begin{array}{l}\text { No } \\
\text { Fewer than } 1 \text { time per day } \\
\text { One or more times/day }\end{array}$ & $\begin{array}{c}12(36.4) \\
6(18.2) \\
15(45.4)\end{array}$ & $\begin{array}{c}12(60.0) \\
6(30.0) \\
2(10.0)\end{array}$ & 0.028 \\
\hline Time of mouthwash use (years) & $\begin{array}{c}\mathrm{N} \\
\text { Variation } \\
\text { Median } \\
\text { Mean (standard deviation) }\end{array}$ & $\begin{array}{c}21 \\
0.2-18 . \\
5 \\
6.3(4.8)\end{array}$ & $\begin{array}{c}8 \\
2-15 . \\
7.5 \\
8.0(5.3)\end{array}$ & 0.428 \\
\hline $\begin{array}{c}\text { Time, use of mouthwash } \\
\text { (years) }\end{array}$ & $\begin{array}{c}\text { Does not use } \\
\quad \leq 40 \\
>40\end{array}$ & $\begin{array}{c}12(36.4) \\
12(36.4) \\
9(27.3)\end{array}$ & $\begin{array}{l}12(60.0) \\
4(20.0) \\
4(20.0)\end{array}$ & 0.233 \\
\hline Who indicated it? & $\begin{array}{c}\text { I use it on my own account } \\
\text { Dentist } \\
\text { Daughter } \\
\text { Doctor }\end{array}$ & $\begin{array}{l}13(61.9) \\
5(23.8) \\
1(4.8) \\
2(9.5)\end{array}$ & $\begin{array}{l}7(87.5) \\
1(12.5) \\
0(0.0) \\
0(0.0)\end{array}$ & NA \\
\hline Reason for use & $\begin{array}{c}\text { Breath } \\
\text { Cleaning } \\
\text { Cigarette odor } \\
\text { Due to Lesion }\end{array}$ & $\begin{array}{c}3(14.3) \\
15(71.4) \\
1(4.8) \\
2(9.5)\end{array}$ & $\begin{array}{c}1(12.5) \\
6(75.0) \\
0(0.0) \\
1(12.5)\end{array}$ & NA \\
\hline
\end{tabular}

$\mathrm{p}$-value obtained by the chi-square frequencies test $N A=$ not statistically assessable

Table 3 | Distribution of variables referring to smoking and alcohol consumption according to group.

\begin{tabular}{|c|c|c|c|c|}
\hline Variable & Category / Measures & $\begin{array}{r}\text { Case } \\
\text { Freq. \% }\end{array}$ & & $p$-value \\
\hline Smoker & $\begin{array}{l}\text { No } \\
\text { Yes }\end{array}$ & $\begin{array}{c}7(21.2) \\
\mathbf{2 6}(\mathbf{7 8 . 8})\end{array}$ & $\begin{array}{l}12(60.0) \\
8(40.0)\end{array}$ & 0.004 \\
\hline Packs cigarettes/ year & $\begin{array}{c}\mathrm{N} \\
\text { Variation } \\
\text { Median } \\
\text { Mean (standard deviation) }\end{array}$ & $\begin{array}{c}26 \\
2-150 . \\
\mathbf{4 5 . 5} \\
48.0(34.1)\end{array}$ & $\begin{array}{c}8 \\
0.3-50 . \\
\mathbf{2 7 . 5} \\
24.4(19.1)\end{array}$ & 0.044 * \\
\hline Packs cigarettes/ year & $\begin{array}{l}\text { Does not smoke } \\
\quad \leq 20 \\
>20\end{array}$ & $\begin{array}{c}7(21.2) \\
6(18.2) \\
\mathbf{2 0}(\mathbf{6 0 . 6 )}\end{array}$ & $\begin{array}{l}12(60.0) \\
3(\mathbf{1 5 . 0}) \\
5(25.0)\end{array}$ & 0.013 \\
\hline Alcohol consumer & $\begin{array}{l}\text { No } \\
\text { Yes }\end{array}$ & $\begin{array}{l}10(30.3) \\
23(69.7)\end{array}$ & $\begin{array}{c}7(35.0) \\
13(65.0)\end{array}$ & 0.723 \\
\hline Consumes alcohol & $\begin{array}{c}\mathrm{N} \\
\text { Variation } \\
\text { Median } \\
\text { Mean (standard deviation) }\end{array}$ & $\begin{array}{c}21 \\
22.5-14062.5 . \\
\mathbf{1 6 4 5 . 0} \\
3124.4(3898.6)\end{array}$ & $\begin{array}{c}12 \\
5.8-862.5 . \\
\mathbf{5 4 . 8} \\
156.1(247.2)\end{array}$ & $0.031 *$ \\
\hline $\begin{array}{l}\text { Alcohol consumption (ml } \\
\text { day/year) }\end{array}$ & $\begin{array}{c}\text { Does not consume } \\
\leq 40 \\
>40\end{array}$ & $\begin{array}{c}12(36.4) \\
5(15.2) \\
16(48.5)\end{array}$ & $\begin{array}{c}8(40.0) \\
10(50.0) \\
2(10.0)\end{array}$ & 0.004 \\
\hline
\end{tabular}

p-value obtained by the chi-square frequencies test. 


\section{DISCUSSION}

Hooper et al. ${ }^{13}$ reported that the majority of cases of oral cancer were related to the use of tobacco and alcohol consumption. Other studies have also put forward different hypotheses, such as those of Winn et al. ${ }^{14}$, who indicated possible risk factors as being teeth in a poor state of conservation, inadequate oral hygiene, and the use of mouthwashes, particularly among non-users of tobacco and alcohol. In addition, Homann et al. ${ }^{6}$ reported that, by means of their epidemiological data, they could support that poor oral hygiene was an independent risk factor for cancer of the mouth, whereas Tsai et al. ${ }^{15}$ suggested that improvement in oral hygiene practices could bring additional benefits when thinking about the prevention of cancer of the mouth.

It has been put forward that acetaldehyde, the first metabolite of ethanol, has demonstrated multiple mutagenic effects, and is carcinogenic to animals. Furthermore, it has been suggested that acetaldehyde may be produced by the metabolism of microorganisms present in the mouth ${ }^{13}$ and poor oral hygiene may elevate the acetaldehyde level in saliva. Studies have also demonstrated that Candida albicans could produce significant quantities of acetaldehyde, carcinogenic in clinically relevant concentrations. ${ }^{13,16}$

Based on the diversity of information in the literature stating poor oral hygiene and bad state of conservation of the teeth could be predisposing factors for cancer of the mouth, our study evaluated some oral hygiene habits and identified that over $81 \%$ of patients with cancer did not make use of dental floss. Thus, these numbers led us to note that those who did not use dental floss were 4 times the number of those who use it, and this datum was statistically significant. Due to the sample size, we could not affirm that whoever does not use dental floss has a higher risk of developing cancer of the mouth and oropharynx; however, it led us to think that care of oral hygiene and health must not be neglected. The data observed as regarding dental floss are in agreement with another datum observed, in which over $87 \%$ of the patients in the case group did not observe bleeding in the gingiva, a datum also observed in the control group. The aspect that most drew attention was a datum inverse to all the previous data in the literature, in which the case group reported brushing their teeth more times a day than the control group, no matter that this difference was marginally significant. We imagined this information was due to the greater concern about oral hygiene as soon as the diagnosis of the lesion was made, and the need for maintaining oral hygiene during antineoplastic treatment.

Mouthwashes have been used for a long time as antiseptic and to refresh breath, ${ }^{17}$ as astringent, calming, ${ }^{8,18}$ and as a method of delivering antimicrobial agents to all the sites of the oral mucosa, thus providing a complementary plaque control mechanism. ${ }^{19}$

The present study, seeking to evaluate the use of mouthwashes in patients with cancer of the mouth and oropharynx, and based on a vast and diversified literature regarding methodologies and results, verified that of the 33 patients studied in the case group, 21 reported making use of mouthwashes, totaling over $63 \%$. The patients in the control group made less use of mouthwashes compared with the case group ( $\mathrm{p}=0.028)$, which was shown to be a statistically significant association. This datum corroborates the findings of a large number of studies in which association of the use of mouthwashes and cancer have been evaluated..$^{20-22}$

The occasion in which the use of mouthwashes began was also questioned during the study, when it was observed that out of a total of 21 patients who made use of them, 15 began to use them before diagnosis of the tumor, with a mean time of 5.5 years, and 6 patients began using them after diagnosis. The longest time of use reported before diagnosis 
was 15 years and the shortest time, 6 months. This information appeared to us to be important, considering that in an endeavor the make this correlation, some studies did not suggest the possibility that the use of mouthwashes could have been started after the development of cancer, and thereby would lose their etiological or facilitating nature.

Of the 15 cases that began mouthwash use before diagnosis, 11 were smokers and 4 were not. The mean consumption of cigarettes in these patients was 22.6 cigarettes per day. Six patients reported they did not consume alcohol, and 9 did. This information also corroborates the literature, in which the large majority of mouthwash users have been observed to be smokers and alcohol consumers.

As in the study of Wirth et al. ${ }^{20}$, our study also questioned the reason for using mouthwash. The most prevalent reason was cleaning, reported by 15 patients, whereas improving breath was the reason given by 3 patients; 2 patients said they used mouthwashes to mask the odor of cigarettes. Two patients used mouthwash with the purpose of treating the lesion. On the other hand, for Wirth et al. ${ }^{20}$, the main benefits reported were improving bad breath (75\%), elimination of bacteria (68\%), and reduction in plaque formation (47\%).

Mouthwashes with alcohol were used by 17 patients, and 3 used the type without alcohol. Of the 17 patients, 5 used more than one type of mouthwash with alcohol, one used only Plax ${ }^{\circledR}, 2$ Malvona ${ }^{\circledR}, 3$ Periogard ${ }^{\circledR}, 5$ Listerine ${ }^{\circledR}$ and one was unable to report the brand. This datum, neglected by older articles in the literature, could not be statistically evaluated in our study due to the small casuistic.

Even in view of this casuistic, we may suggest that the risk of developing cancer for the group that made use of oral mouth is almost 3 times higher than for those who do not use it, and when we stratified for the main risk factors, only when we considered individually who drank, this risk rose to being 4 times higher. Therefore, the use of oral mouthwash appears to be a risk factor. We reiterate that a larger casuistic would be necessary to affirm this datum.

One of the failures most perceived in the studies with the object of associating mouthwashes containing alcohol with cancer was the lack of standardization regarding the type of mouthwash, presence of alcohol, and its concentration. This datum was questioned and evaluated by us; however, our casuistic did not allow for statistical tests to be performed. The data found in this study certainly do not allow us to affirm that alcohol in mouthwashes plays any role in the development of cancer, but, once again, it made us think that in the same way as this association cannot be affirmed, it cannot be completely denied.

From the results of this study, we concluded that although we used a small sample of cases and controls, by means of stratified analysis the use of mouthwashes was found to be approximately 4 times higher in patients who consumed alcoholic beverages.Nonetheless, no increase in risk was observed with the use of mouthwashes in patients who did not drink, and who smoked or not. The studied patients with cancer of the mouth and oropharynx brushed their teeth more than once a day, used more mouthwashes and less dental floss when compared with the control patients.

\section{REFERENCES}

1. Weinberg MA. Oral cancer risk factors and the Pharmacist's role in intervention. US Pharm. 2006;8:79-84.

2. Warnakulasuriya S. Global epidemiology of oral and oropharyngeal cancer. Oral Oncol. 2009Apr-May;45(4-5):309-16. doi: 10.1016/j.oraloncology.2008.06.002.

3. Instituto Nacional de Câncer José Alencar Gomes da Silva. Estimativa 2014: incidência de câncer no Brasil. Rio de Janeiro: INCA;2014.

4. Mashberg A, Barsa P, Grossman ML. A study of the relationship between mouthwash use and oral and pharyngeal 
cancer. J Am Dent Assoc. 1985 May;110(5):731-4.doi: http:// dx.doi.org/10.14219/jada.archive.1985.0422.

5. Toporcov TN, Antunes JL, Tavares MR. Fat food habitual intake and risk of oral cancer. Oral Oncol. 2004 Oct;40(9):925-31.doi: http://dx.doi.org/10.1016/j.oralonco$\operatorname{logy} .2004 .04 .007$.

6. Homann N, Jousimies-Somer H, Jokelainen K, Heine R, Salaspuro M. High acetaldehyde levels in saliva after ethanol consumption: methodological aspects and pathogenetic implications. Carcinogenesis. 1997 Sep;18(9):1739-43.doi: 10.1093/carcin/18.9.1739.

7. Lemos-Júnior CA, Villoria GEM. Reviewed evidence about the safety of the daily use of alcohol-based mouthrinses. Braz Oral Res. 2008;22Suppl1:S24-31.doi: http://dx.doi. org/10.159o/S1806-83242008000500005.

8. Fossati ACM, Kappel EP, Dobrinsky L, Amenabar JM, Lamers ML, Silveira HED.Alteraciones de la mucosa bucal causadas por la asociación entre el tabaco y los colutorios bucales con una concentración de alcohol del 26,9\%. Rev Cubana Estomatol [Internet]. 2006 Sep [citado 2016 Jun 04];43(3). Disponible en: http://scielo.sld.cu/scielo.php?script=sci_arttext\&pid=So034-75072006000300003\&lng=es.

9. Claffey N. Essential oil mouthwashes: a key component in oral health management. J ClinPeriodontol. 2003 June;30Suppl 5:S22-4.doi: 10.1034/j.1600-051X.30.s5.8.x

10. Silverman SJr,Wilder R. Antimicrobial mouthrinse as part of a comprehensive oral care regimen:safety and compliance factors. J Am Dent Assoc. 2006 Nov;137Suppl 3:S22-26.doi: http://dx.doi.org/10.14219/jada.archive.2006.0406.

11. Gandini S, Negri E, Boffetta P, La Vecchia C, Boyle P. Mouthwash and oral cancer risk quantitative meta-analysis of epidemiologic studies. Ann Agric Environ Med. 2012;19(2):17380.

12. Lachenmeier DW. Safety evaluation of topical applications of ethanol on the skin and inside the oral cavity.J Occup Med Toxicol. 2008 Nov 13;3:26. doi: 10.1186/1745-6673-3-26.

13. Hooper SJ, Wilson MJ, Crean SJ. Exploring the link between microorganisms and oral cancer: a systematic review of the literature. Head Neck. 2009 Sep;31(9):1228-39. doi: 10.1002/ hed.21140.
14. Winn DM, Blot WJ, McLaughlin JK, Austin DF, Greenberg RS, Preston-Martin S, et al. Mouthwash use and oral conditions in the risk of oral and pharyngeal cancer.Cancer Res. 1991 Jun;51(11):3044-7.

15. Tsai ST, Wong TY, Ou CY, Fang SY, Chen KC, Hsiao JR, et al. The interplay between alcohol consumption, oral hygiene, $\mathrm{ALDH} 2$ and $\mathrm{ADH} 1 \mathrm{~B}$ in the risk of head and neck cancer.Int J Cancer. 2014 Nov;135(10):2424-36. doi: 10.1002/ijc.28885. 16. Uittamo J, Siikala E, Kaihovaara P, Salaspuro M, Rautemaa R. Chroniccandidosis and oral cancer in APECED-patients: production of carcinogenic acetaldehyde from glucose and ethanol by Candida albicans. Int J Cancer. 2009 Feb 1;124(3):754-6. doi: 10.1002/ijc.23976.

17. Adams D, Addy M. Mouthrinses. AdvDent Res. 1994 Jul;8(2):291-301.doi: 10.1177/08959374940080022401.

18. Carretero-Peláez MA, Esparza-Gómez GC, Figuero-Ruiz E, Cerero-Lapiedra R. Colutorios con alcohol y su relación con el cáncer oral. Análisis crítico de la literatura. MedOral PatolOral CirBucal (Ed.impr.) [Internet]. 2004 Abr [citado 2016 jun 04];9(2):116-23. Disponible en: http://scielo.isciii.es/scielo.php?script=sci_arttext\&pi$\mathrm{d}=\mathrm{S} 1698-44472004000200003 \& \operatorname{lng}=\mathrm{es}$.

19. Barnett ML. The rationale for the daily use of an antimicrobial mouthrinse. J Am Dent Assoc. 2006 Nov;137Suppl 3: S1621.doi: http://dx.doi.org/10.14219/jada.archive.2006.0408.

20. Wirth T, Kawecki MM, Reeve J, Cunningham C, Bovaird I, Macfarlane TV. Can alcohol intake from mouthwash be measured in epidemiological studies? Development and validation of mouthwash use questionnaire with particular attention to measuring alcohol intake from mouthwash. J Oral Maxillofac Res. 2012 Oct;3(3):e1. doi: 10.5037/jomr.2012.3301. 21. Bahna P, Hanna HA, Dvorak T, Vaporciyan A, Chambers M, Raad I. Antiseptic effect of a novel alcohol-free mouthwash: a convenient prophylactic alternative for high-risk patients. Oral Oncol. 2007 Feb;43(2):159-64.doi: http://dx.doi.org/10.1016/j.oraloncology.2006.02.002.

22. Guha N, Boffetta P, WünschFilho V, ElufNeto J, Shangina $\mathrm{O}$, Zaridze D, et al. Oral health and risk of squamous cell carcinoma of the head and neck and esophagus: results of two multicentric case-control studies.Am J Epidemiol. 2007 Nov;166(10):1159-73.doi: 10.1093/aje/kwm193. 